\title{
Variation in soil net mineralization rates with dissolved organic carbon additions
}

\author{
Alison H. Magill*, John D. Aber \\ Complex Systems Research Center, University of New Hampshire, Morse Hall, Room 481, Durham, NH 03824, USA
}

Accepted 29 September 1999

\begin{abstract}
Northeastern forest are generally considered to be nitrogen limited, even though soil microbial populations may in fact be limited by the amount of carbon required as an energy source. Field studies have shown that with increasing $\mathrm{N}$ availability, net mineralization rates increase initially but then decrease over time. One possible reason for a reduction in net mineralization rates is that labile soil carbon, such as dissolved organic carbon (DOC), becomes depleted. Five-week laboratory incubations of organic and mineral soil samples with different carbon amendments were performed in order to determine the effect of carbon quality on potential net nitrification and net mineralization rates. Net nitrogen immobilization was greater in soils incubated with glucose amendments than those incubated with more complex carbon compounds such as humic acid. Although this resulted in lower net mineralization rates overall, net immobilization is an indicator of immediate microbial response to the carbon substrate. Net nitrification was not detected, likely due to the short duration of the incubations. Measurements of gross mineralization rates may be necessary to see an overall effect of carbon substrate on $\mathrm{N}$ cycling in these soils. (C) 2000 Elsevier Science Ltd. All rights reserved.
\end{abstract}

Keywords: Nitrogen immobilization; Mineralization; Dissolved organic carbon (DOC); Forest soils

\section{Introduction}

Availability of soil carbon and nitrogen as nutrients for microbial growth can be an important factor regulating forest nutrient cycling. Organic matter inputs to the soil, in the form of plant or animal detritus, are a primary source of both carbon and nitrogen (Gosz et al., 1973; Aber and Melillo, 1991). Since soil microflora and fauna are the initial decomposers of organic material, decomposition rates are intimately linked with the nutrient supply to these microorganisms.

Decomposition rates have been well studied (e.g. Swift et al., 1979; Aber and Melillo, 1982; Melillo et al., 1982; McClaugherty et al., 1985). Litter quality is the most likely factor to regulate microbial activity if

\footnotetext{
* Corresponding author. Tel.: + 1-603-862-4098; fax: +1-603-8620188 .

E-mail address: alison.magill@unh.edu (A.H. Magill).
}

both temperature and moisture regimes are at acceptable levels for microbial growth (Meentemeyer, 1978; White et al., 1988). Studies have shown that of the three major classes of carbon compounds (extractives, cellulose and lignin), extractives are rapidly consumed or converted during the initial stages of decomposition (McClaugherty, 1983; Aber et al., 1990). In addition, nitrogen is immobilized from the soil solution and weight loss is rapid (Aber and Melillo, 1982), indicating that microbial activity is high. The disappearance of extractives (low molecular weight polyphenols and carbohydrates) leaves behind the more recalcitrant carbon compounds and coincides with a reduction in decomposition rates thus emphasizing the importance of these compounds to the microbial population.

Temperate forest ecosystems are generally considered to be nitrogen limited overall (Mitchell and Chandler, 1939; Aber et al., 1989). It is possible, however, that microbial growth could be limited by lack of labile carbon as an available energy source. Results 
from a field study of long-term nitrogen additions at the Harvard Forest, Petersham MA (Aber et al., 1993; Magill et al., 1997), showed an initial increase of nitrogen mineralization rates with $\mathrm{NH}_{4} \mathrm{NO}_{3}$ fertilizer additions (buried bag technique (Nadelhoffer et al., 1983; Pastor et al., 1984)) and a subsequent decline in the third year, indicating that some factor other than nitrogen availability may have been limiting mineralization. This same pattern was seen in other nitrogen amendment studies (Söderström et al., 1983; Magill et al., 1996). If nitrogen availability is in excess of microflora needs and carbon availability does not increase via throughfall, root exudates or decomposition, then $\mathrm{N}$ mineralization would be limited instead by the lack of a labile carbon source, such as dissolved organic carbon (DOC).

Our purpose was to estimate the effect of different carbon substrates on potential net mineralization $\left(\mathrm{NH}_{4}^{+}-\mathrm{N}+\mathrm{NO}_{3}^{-}-\mathrm{N}\right)$ and net nitrification $\left(\mathrm{NO}_{3}^{-}-\mathrm{N}\right.$ only) rates of both organic and mineral soil. We hypothesized that structurally simpler, smaller compounds (sugars) would increase net mineralization or net nitrification rates, whereas larger, more complex compounds would have little effect on rates in the short-term. The standard laboratory aerobic incubation technique of Stanford and Smith (1972) was modified to allow for $\mathrm{KCl}$ extractions rather than consecutive leaching of samples.

\section{Methods}

\subsection{Sample collection}

Soil samples were collected from a mixed hardwood stand adjacent to the Chronic Nitrogen Amendment plots on Prospect Hill at the Harvard Forest, Petersham, MA (see Aber et al. (1993) for site description). Multiple cores were collected in late October 1993, divided into $\mathrm{O}$ and $\mathrm{M}$ horizon sub-samples in the field, then refrigerated for 6 weeks prior to incubation. The mineral horizon was sampled to a depth of $10 \mathrm{~cm}$. Soil was homogenized by passing the sample through a 5.6 $\mathrm{mm}$ mesh sieve followed by a $2.0 \mathrm{~mm}$ mesh sieve. Soil moisture of the homogenized sample was determined by weighing the sample, drying for $48 \mathrm{~h}$ at $105^{\circ} \mathrm{C}$ and re-weighing.

\subsection{Carbon amendments}

Six carbon treatments were used (Table 1) and were chosen to cover a wide range of degradability. The concentration of carbon to be added was calculated as an amount equivalent to the total DOC leached from lab-incubated, decomposing leaf litter over 4 weeks (Magill and Aber, 2000). The average value (for nine tree species) was $21.4 \mathrm{mg}$ DOC g $\mathrm{g}^{-1}$ litter where DOC is defined as those compounds passing through a 0.7 $\mu \mathrm{m}$ filter. Carbon concentrations were converted to a per soil area value using data from the Chronic Nitrogen plots (Aber et al., 1993; Magill et al., 1997) and were $8.88 \mathrm{mg} \mathrm{C}$ per $25 \mathrm{~g}$ soil for the forest floor (FF) and $6.66 \mathrm{mg} \mathrm{C}$ per $50 \mathrm{~g}$ soil for the mineral soil (MS).

The actual carbon amendment concentrations were determined from the field capacity of the soils and the current moisture content. Field capacity measurements from the Chronic Nitrogen plot soils were used in this calculation. These values were 3.34 and $0.70 \mathrm{~g} \mathrm{H}_{2} \mathrm{O}$ $\mathrm{g}^{-1}$ dry soil for the forest floor and mineral soil, respectively (R. Bowden, personal communication). The total volume of solution used to bring the soil to approximately $80 \%$ of field capacity was $7 \mathrm{ml}$ of solution per $25 \mathrm{~g}$ of $\mathrm{FF}(81 \%)$ and $9 \mathrm{ml}$ of solution per $50 \mathrm{~g}$ of MS (83\%).

After determining the volume of solution to be added, actual concentrations were calculated based on the mg $\mathrm{C}$ per sample to be added. The concentration for the FF was $1268 \mathrm{mg} \mathrm{l}^{-1}$ and rounded to $1200 \mathrm{mg}$ $\mathrm{C}^{-1}$. For simplicity, although the actual amount calculated for the MS was $740 \mathrm{mg} \mathrm{1}^{-1}, 1200 \mathrm{mg} \mathrm{C}^{-1}$ was used. Final concentrations are in Table 1. Leaf leachate solution was hickory litter extract from the litter leachate experiment (Magill and Aber, 2000).

\subsection{Experimental design}

The experimental design consisted of five replicates

Table 1

Summary of treatments and initial soil characteristics. FF are forest floor samples and MS are mineral soil samples. NA=data not available.

\begin{tabular}{|c|c|c|c|c|}
\hline Treatment & Chemical & $\begin{array}{l}\text { Carbon concentration } \\
\left(\mathrm{mg} \mathrm{C}^{-1}\right)\end{array}$ & Solution $\mathrm{pH}$ & $\begin{array}{l}\text { Soil moisture } \\
\text { (fraction of dry weight) }\end{array}$ \\
\hline Control & deionized water & $<2$ & 7.2 & $\mathrm{FF}=3.16, \mathrm{MS}=0.620$ \\
\hline Leaf leachate & hickory leaf extract & 185 (as DOC) & NA & $\mathrm{FF}=3.23, \mathrm{MS}=0.632$ \\
\hline Cinnamic acid & 3-phenylpropenoic acid $\left(\mathrm{C}_{9} \mathrm{H}_{8} \mathrm{O}_{2}\right)+\mathrm{NaOH}$ & 1200 & 11.5 & $\mathrm{FF}=3.26, \mathrm{MS}=0.636$ \\
\hline Humic acid & unknown structure $(43.8 \% \mathrm{C}, 3.5 \% \mathrm{H}, 0.56 \% \mathrm{~N})$ & 1200 & 9.7 & $\mathrm{FF}=3.22, \mathrm{MS}=0.625$ \\
\hline Glucose, low & D-glucose, anhydrous $\left(\mathrm{C}_{6} \mathrm{H}_{12} \mathrm{O}_{6}\right)$ & 1200 & NA & $\mathrm{FF}=3.26, \mathrm{MS}=0.634$ \\
\hline Glucose, high & D-glucose, anhydrous $\left(\mathrm{C}_{6} \mathrm{H}_{12} \mathrm{O}_{6}\right)$ & 2400 & NA & $\mathrm{FF}=3.21, \mathrm{MS}=0.627$ \\
\hline
\end{tabular}


of each treatment for each soil horizon, equalling a total of 60 samples. The bulk homogenized soil samples were sub-sampled five times for $\mathrm{KCl}$ extraction and soil moisture determination. The mean moisture and nitrogen concentrations from these were used to calculate initial soil conditions. In addition, one soil moisture sample was taken from each treatment to determine the soil moisture after the carbon solution was added.

The total amount of soil needed for the five replicates (e.g. $\mathrm{FF}=125 \mathrm{~g}$ ) was placed in a shallow pan, the total volume of carbon amendment solution added and the soil thoroughly mixed. Samples were then weighed into polyethylene bags, twist-tied and placed in a box. Initial sample weights (after the carbon amendment was added) were approximately $30 \mathrm{~g}$ for the FF and $55 \mathrm{~g}$ for the MS.
Air temperature was monitored throughout the incubation and fluctuated from 15.5 to $24.5^{\circ} \mathrm{C}$. Subsamples of the soils were extracted initially, after 1 week (week 1) and after 5 weeks (week 5), in $2 \mathrm{~N} \mathrm{KCl}$. Approximately $10 \mathrm{~g}$ soil was added to $100 \mathrm{ml} \mathrm{KCl}$, shaken and allowed to extract for $48 \mathrm{~h}$, then filtered using a 0.1 $\mu \mathrm{m}$ glass fiber filter. Soil extracts were analysed for $\mathrm{NH}_{4}^{+}-\mathrm{N}$ and $\mathrm{NO}_{3}^{-}-\mathrm{N}$ using a Bran \& Luebbe Traacs Autoanalyser. $\mathrm{NH}_{4}^{+}-\mathrm{N}$ was measured using the Berthelot reaction (Technicon Method 780-86T; Technicon Industrial Systems, 1978); $\mathrm{NO}_{3}^{-}-\mathrm{N}$ was determined using a hydrazine sulfate reduction technique (Technicon Method 782-86T; Technicon Industrial Systems, 1977). Limit of detection for both methods is $0.2 \mathrm{mg}$ $1^{-1} \pm 0.02$. Soil moisture was determined for each replicate by drying the soils for $48 \mathrm{~h}$ at $105^{\circ} \mathrm{C}$.

Net mineralization and nitrification were calculated
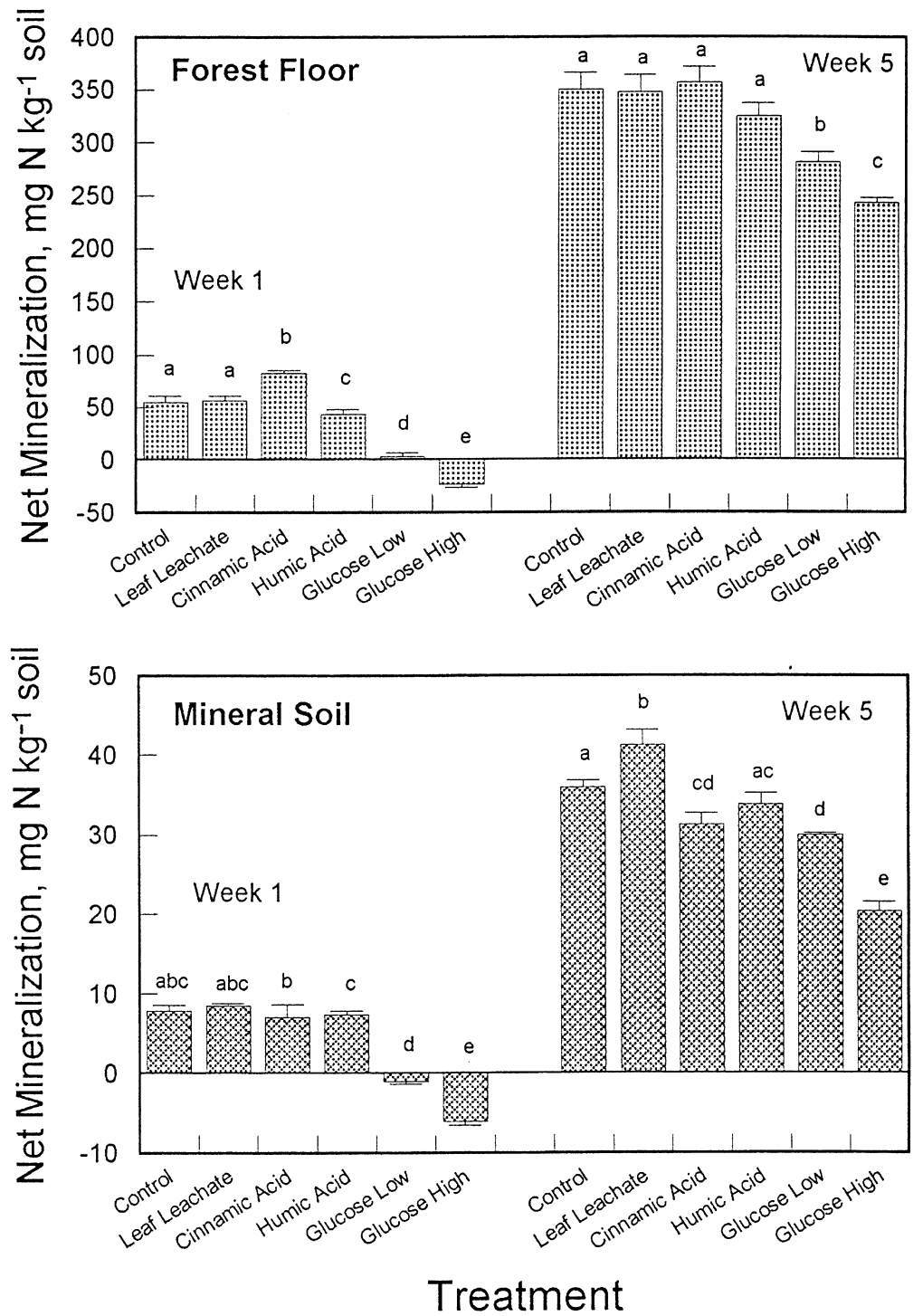

Fig. 1. Net mineralization rates for incubated soil samples. Bars with the same letter (within the same week and soil type) are not significantly different at the $P=0.05$ level. 
for the incubation period. $\mathrm{NO}_{3}^{-}-\mathrm{N}$ and $\mathrm{NH}_{4}^{+}-\mathrm{N}$ were converted to $\mathrm{mg} \mathrm{N} \mathrm{kg}^{-1}$ soil and the initial extract values subtracted from the incubated values. One-way ANOVA was used to determine statistically significant differences between treatments at the $P=0.05$ level.

\section{Results and discussion}

Net nitrification did not occur in these soils during the incubation; no $\mathrm{NO}_{3}^{-}-\mathrm{N}$ was detected in the initial or incubated soils. Other laboratory studies have demonstrated that there may be a long lag period before nitrification occurs (Gosz and White, 1986; Hart et al., 1994) and, thus, these incubations may not have been long enough to induce nitrification. There were, however, significant differences in net mineralization rates between treatments for both the soil types (Fig. 1). Since net nitrification was not detected in these samples, net mineralization includes only $\mathrm{NH}_{4}^{+}-$ $\mathrm{N}$.

The original hypothesis predicted that net mineralization would increase with the addition of glucose, a simple sugar. If extracts had been performed only at week 5, results would have shown the glucose treatments to produce lower mineralization rates than any other treatment. However, data from the week 1 extracts showed a net nitrogen immobilization for both soil types under the glucose high treatment and only for the mineral soil under the glucose low treatment. These results indicate that, in the presence of a labile carbon source, available soil nitrogen was rapidly immobilized. If the quantity of nitrogen immobilized by the glucose high treatment soils after week 1 were added to the total net mineralization after week 5 (i.e. if the amount immobilized was actually mineralized instead), rates would still be significantly lower than the controls. However, measurement of net immobilization does indicate that microbial activity was stimulated.

Winsor and Pollard (1956) found a similar pattern of rapid $\mathrm{N}$ immobilization in garden soils with additions of ammonium sulfate and varying amounts of sucrose. $\mathrm{N}$ immobilization reached its maximum within $2 \mathrm{~d}$, after which nitrification began to convert ammonium to nitrate. Immobilization increased proportionally with increasing $\mathrm{C}$-to- $\mathrm{N}$ ratio of additions. Cook and Allen (1992) measured potential mineralization rates of previously cultivated old-field soils. Samples were incubated for 14, 35, 105 and $210 \mathrm{~d}$. They found no clear relationship between mineralization rates and DOC concentrations of the soil, although there appeared to be a decrease in mineralization rate in response to DOC pool size as the incubation proceeded.

Johnson and Edwards (1979) conducted a number of $30 \mathrm{~d}$ laboratory incubations on soils from mixed hardwood stands in Tennessee. Soils were collected from plots 19 and $171 \mathrm{~d}$ following field applications of $240 \mathrm{~g} \mathrm{~m}^{-2}$ sucrose. Thirty-day net $\mathrm{N}$ mineralization rates were reduced by two-thirds in the $19 \mathrm{~d}$ samples and by half in the $171 \mathrm{~d}$ samples, as compared to rates of soils from untreated plots. This reduction in net mineralization rate could be due to an increase in $\mathrm{N}$ immobilization stimulated by increased sucrose availability.

The results from these studies support our findings, showing that labile carbon appears to increase net $\mathrm{N}$ immobilization rather than net $\mathrm{N}$ mineralization. Addition of the other, more recalcitrant carbon compounds did not reveal any clear stimulation of either net immobilization or net mineralization, relative to controls. Johnson and Edwards (1979) also found no substantial effect on net $\mathrm{N}$ mineralization or net nitrification rates when litter or root extracts were added to soils during $30 \mathrm{~d}$ laboratory incubations.

Although net mineralization rates appear lower or not significantly different from non-treated samples, carbon additions may in fact have a large influence on gross turnover rates as nitrogen is immobilized and remineralized. As our study demonstrates, net immobilization occurred after 1 week of incubation and therefore studies that do not include short-term measurements ( $<1$ week) would see only a lower final net mineralization rate. Hart et al. (1994) measured gross mineralization and nitrification rates over $456 \mathrm{~d}$ in forest soils labeled with ${ }^{15} \mathrm{NH}_{4}$ and ${ }^{5} \mathrm{NO}_{3}$. They found that gross mineralization rates were highly correlated with $\mathrm{CO}_{2}$ evolution (i.e. microbial respiration) where net mineralization rates were not. In conclusion, immobilization of nitrogen by heterotrophic organisms appears to be stimulated by additions of labile carbon. Measurement of net mineralization and nitrification rates alone may not accurately reflect this stimulation of microbial activity even though populations increase as $\mathrm{N}$ is assimilated into microbial biomass.

\section{Acknowledgements}

The authors wish to thank Gloria Quigley, Jim Muckenhoupt and Amy Simoneau for assistance in the field and laboratory. Additional thanks goes to Richard Bowden for soils data and to Margaret Lefer for helpful comments on the manuscript.

\section{References}

Aber, J.D., Melillo, J.M., 1982. Nitrogen immobilization in decaying hardwood leaf litter as a function of initial nitrogen and lignin content. Canadian Journal of Botany 60, 2263-2269. 
Aber, J.D., Nadelhoffer, K.J., Steudler, P., Melillo, J.M., 1989. Nitrogen saturation in northern forest ecosystems. Bioscience 39, 378-386.

Aber, J.D., Melillo, J.M., McClaugherty, C.A., 1990. Predicting long-term patterns of mass loss, nitrogen dynamics and soil organic matter formation from initial fine litter chemistry in temperate forest ecosystems. Canadian Journal of Botany 68, 22012208.

Aber, J.D., Melillo, J.M., 1991. Terrestrial Ecosystems. Saunders College Publishing, Philadelphia.

Aber, J.D., Magill, A.H., Boone, R., Melillo, J.M., Steudler, P., Bowden, R., 1993. Plant and soil responses to chronic nitrogen additions at the Harvard Forest, Massachusetts. Ecological Applications 3, 156-166.

Cook, B.D., Allen, D.L., 1992. Dissolved organic carbon in old field soils: total amounts as a measure of available resources for soil mineralization. Soil Biology \& Biochemistry 24, 585-594.

Gosz, J.R., Likens, G.E., Bormann, F.H., 1973. Nutrient release from decomposing leaf and branch litter in the Hubbard Brook Forest, New Hampshire. Ecological Monographs 43, 173-191.

Gosz, J.R., White, C.S., 1986. Seasonal and annual variation in nitrogen mineralization and nitrification along an elevational gradient in New Mexico. Biogeochemistry 2, 281-297.

Hart, S.C., Nason, G.E., Myrold, D.D., Perry, D.A., 1994. Dynamics of gross nitrogen transformations in an old-growth forest: the carbon connection. Ecology 75, 880-891.

Johnson, D.W., Edwards, N.T., 1979. The effects of stem girdling on biogeochemical cycles within a mixed deciduous forest. II. Soil nitrogen mineralization and nitrification rates. Oecologia 40, 259271.

Magill, A.H., Downs, M.R., Nadelhoffer, K.J., Hallett, R.A., Aber, J.D., 1996. Forest ecosysten response to four years of chronic nitrate and sulfate additions at Bear Brooks Watershed, Maine, USA. Forest Ecology and Management 84, 29-37.

Magill, A.H., Aber, J.D., Hendricks, J.J., Bowden, R.D., Steudler, P.A., Melillo, J.M., 1997. Biogeochemical response of forest ecosystems to simulated chronic nitrogen deposition. Ecological Applications 7, 402-415.

Magill, A.H., Aber, J.D., 2000. Dissolved organic carbon and nitrogen relationships in forest litter as affected by nitrogen deposition. Soil Biology \& Biochemistry, 32, 603-613.

McClaugherty, C.A., 1983. Soluble polyphenols and carbohydrates in throughfall and leaf litter decomposition. Acta Oecologica Oecologia Generalis 4, 375-385.

McClaugherty, C.A., Pastor, J., Aber, J.D., 1985. Forest litter decomposition in relation to soil nitrogen dynamics and litter quality. Ecology 66, 266-275.

Meentemeyer, V., 1978. Macroclimate and lignin control of litter decomposition rates. Ecology 59, 465-472.

Melillo, J.M., Aber, J.D., Mutatore, J.F., 1982. Nitrogen and lignin control of hardwood leaf litter decomposition dynamics. Ecology 63, 621-626.

Mitchell, H.L., Chandler, R.F., 1939. The nitrogen nutrition and growth of certain deciduous trees of northeastern United States. The Black Rock Forest Bulletin No. 11. Cornwall-On-TheHudson, NY.

Nadelhoffer, K.J., Aber, J.D., Melillo, J.M., 1983. Leaf-litter production and soil organic matter dynamics along a nitrogen mineralization gradient in southern Wisconsin (USA). Canadian Journal of Forest Research 13, 12-21.

Pastor, J., Aber, J.D., McClaugherty, C.A., Melillo, J.M., 1984. Aboveground production and $\mathrm{N}$ and $\mathrm{P}$ cycling along a nitrogen mineralization gradient on Blackhawk Island, WI. Ecology 65, 256-268.

Söderström, B., Bååth, E., Lundgren, B., 1983. Decrease in soil microbial activity and biomasses owing to nitrogen amendments. Canadian Journal of Microbiology 29, 1500-1506.

Stanford, G., Smith, S.J., 1972. Nitrogen mineralization potentials of soils. Soil Science Society of America Proceedings 36, 465-472.

Swift, M.J., Heal, O.W., Anderson, J.M., 1979. Decomposition in Terrestrial Ecosystems. University of California Press, Berkeley.

Technicon Industrial Systems, 1977. Nitrate and nitrate in water and seawater: industrial method 158-74W/A. Technicon Industrial Systems, Tarrytown, NY.

Technicon Industrial Systems, 1978. Ammonium in water and seawater: industrial method $154-71 \mathrm{~W} / \mathrm{B}$. Technicon Industrial Systems, Tarrytown, NY.

White, C.S., Moore, D.I., Horner, J.D., Gosz, J.R., 1988. Nitrogen mineralization-immobilization response to field $\mathrm{N}$ or $\mathrm{C}$ perturbations: an evaluation of a theoretical model. Soil Biology \& Biochemistry 20, 101-105.

Winsor, G.W., Pollard, A.G., 1956. Carbon-nitrogen relationships in soil. I. The immobilization of nitrogen in the presence of carbon compounds. Journal of Science of Food and Agriculture 7, 134-141. 